\title{
Stakeholders' Perception of the Implementation of International Financial Reporting Standards (IFRS) in Nigeria
}

\author{
Jonathan A. Okunbor ${ }^{1} \&$ Amos O. Arowoshegbe ${ }^{1}$ (Ph. D, ACA.) \\ ${ }^{1}$ Department of Accounting, Ambrose Alli University, Ekpoma, Edo State, Nigeria \\ Correspondence: Amos O. Arowoshegbe, Department of Accounting, Ambrose Alli University, Ekpoma, Edo State, \\ Nigeria. E-mail: futona4christ2@gmail.com
}

Received: December 30, 2013

Accepted: January 20, 2014

Online Published: January 25, 2014

doi:10.5430/afr.v3n1p67

URL: http://dx.doi.org/10.5430/afr.v3n1p67

\begin{abstract}
This study examined the stakeholders' perception of the adoption of IFRS in Nigeria. It sought to establish among others whether the implementation of IFRS in Nigeria has enhanced the value of financial reporting in the country. The data generated from the questionnaire were analysed using Analysis of Variance (ANOVA). In the study, the opinion of users of financial reports was sought through a cross-sectional survey. The study reveals that significant differences exist in the perceptions of stakeholders regarding the effect of the working of IFRS on the value of financial reports; no considerable differences in their perception about the implementation of IFRS with respect to the improvement on quality of investment decisions; and as a basis for assessing returns on investment and whether comparison of financial reports in Nigeria have been enhanced. Based on these findings, it was recommended that relevant authorities should ensure that organisations comply with established standards when preparing financial statements; and auditors must assert their independence with a view to ensuring that audit reports reflect the actual position of the entity's financial circumstances. Government was further advised to strengthen the Financial Reporting Council of Nigeria with qualified personnel in order to adequately perform its functions.
\end{abstract}

Keywords: Stakeholders' perception, International Reporting Standards, Financial Information, Compatibility, and Transparency

\section{Introduction}

As the operating environment of business becomes more complex and risky, the need for reliable and useful financial information to aid decision making process is of utmost importance. As asserted by Spiceland, Sepe and Tomassini (2001) financial information is reliable, credible and useful when it is used to make informed and timely decisions. Creative accounting has over the years led to the fall of major corporations the world over. Investigations into these issues exposed the loss of several billion dollars due to accounting frauds, errors and irregularities in financial transactions. Some of the executives of the failed corporations were charged for criminal offences and the corporations concerned fined billion of dollars.

Nigeria has also witnessed the incidence of corporate collapse arising from accounting frauds. In October 2006, Cadbury Nigeria Plc, one of the highly respected firms, falsified its accounts, which according to it, has spanned many years. Thus, the shareholders who incurred monumental losses to the tune of N15 billion (\$122 million) sued the board of Cadbury Nigeria Plc and its auditors for breach of duty. When accounting frauds and errors are uncovered, the auditors who are the first professional to be blamed, would claim it is not their responsibility to detect frauds and irregularities and they acted based on the information provided by management of the enterprise concerned. Recently, the Nigerian government sanctioned the audit firms of Akintola Williams Deloitte and Adekanola \& Co for certifying false subsidy claims by marketers. The crisis in the Nigerian banking sector that led to the removal of several chief executives and the near collapse of the capital market is still very fresh in our memories.

Corporate accounting scandals arise with the uncover of material misstatements and irregularities by the directors of public corporations. These frauds usually manifest themselves in the forms misappropriation of funds, overstatement of revenues, understating of expenses, overvaluation of corporate assets and suppression of the existence of liabilities. These frauds are sometimes perpetuated with the cooperation of officials in other corporations or affiliates. 
It is the need for financial reports that would check these ugly trends, that some countries including Nigeria have embraced the International Financial Reporting Standards (IFRS). Nigeria officially adopted IFRS January, 2012.

Nigeria commenced the process of adopting IFRS in 2007. In fact, the Central Bank of Nigeria (CBN) had directed banks to adopt IFRS from 2008 while the Securities and Exchange Commission (SEC) gave 2009 as the starting year.

IFRS are improved accounting standards produced by the International Accounting Standards Board (IASB), an autonomous establishment incorporated in the United States of America (USA) but domiciled in London, United Kingdom. It pronounces financial reporting standards that would promote comparability and transparency of financial reports by organisations across the globe.

The Financial Reporting Council, the body responsible for standards setting in Nigeria asserts that judging from the global financial crisis, it is obvious that nations have strained the present system of differential national accounting standards to its limit. Nations that are truly desirous of moving forward are now aiming to free their countries from the limits of the present system.

The study centres principally on the perception of stakeholders about the adoption and implementation of IFRS in a developing country like Nigeria.

\subsection{Statement of the research Problem}

The numerous corporate failures are indication of lapses in the corporate disclosure practices among organisations globally. These have had harmful effects on the integrity of financial reporting and the auditing profession. The effectiveness and credibility of the profession are subjects of current debate among academics and financial experts at different local and international fora.

As Nigeria begins the adoption of IFRS, there is the need to empirically examine the perception of the key stakeholders towards the implementation of the IFRS. Specifically the research is tailored towards providing answer to the following questions:

(i) Has the adoption of IFRS improved the quality of financial reports in Nigeria?

(ii) Does the adoption of IFRS provide better financial information for investment decisions?

(iii) Does the implementation of IFRS in Nigeria enhance comparability and transparency of financial statements?

\subsection{Objectives of the Study}

The main purpose of the study is to examine the perception of stakeholders on the adoption of IFRS in Nigeria .Specifically, the study sets out to examine whether the adoption of IFRS in Nigeria:

(i) has improved the quality of financial reporting

(ii) produces better information for investment decisions.

(iii) has enhanced comparability and transparency of financial statements.

\subsection{Research hypotheses}

For the purpose of achieving our objective, the hypotheses stated in their null form were put forward:

$\mathrm{H}_{1:}$ Significant difference does not exist in the opinion of stakeholders on the impact of adoption of IFRS on the quality of financial reporting.

$\mathrm{H}_{2:}$ Significant difference does not exist in the opinion of stakeholders regarding the impact of IFRS on the quality of investment decisions.

$\mathrm{H}_{3:}$ The perception of stakeholders on the effects of the implementation of IFRS on comparability and transparency of financial statements is not significantly different among stakeholders

\section{Review of the Literature}

Many studies on the adoption and implementation of IFRS have been carried out globally including Nigeria. These studies focus on both private and public sector organisations. Wilson, Loraver, Adaeze \& Iheanyi (2013) examine the state of readiness of Nigerian academics and accounting practitioners to embrace IFRS adoption. The study focuses on the extent of IFRS familiarity by academics and practitioners; the state of readiness to embrace IFRS by academics and practitioners; and their opinion regarding a proper national transition plan to IFRS adoption. The results showed significant differences between accounting students, lecturers and practitioners with respect to their degree of familiarity with IFRS. The study further shows that Nigeria was not ready for IFRS adoption and review of 
courses in accounting curriculum is the key to the transition of Nigerian corporations to IFRS, followed by 'IFRS training for their employees. An important policy implication of the study is the urgency of accounting curriculum review in the Nigerian tertiary educational institutions to incorporate IFRS and its implementation dimensions.

Some researchers have gone further to look at the adoption of IFRS from the perspective of institutional infrastructure that sustain the implementation of IFRS in Nigeria. For example Isenmila and Adeyemo (2013) studied the perceived impact of Nigerian institutional infrastructure on the mandatory adoption of IFRS, The study concludes that Nigerian institutional infrastructures are potentially strong enough to sustain the ongoing mandatory implementation of IFRS. The findings further show that the Securities and Exchange Commission (SEC) has the highest potential impact on IFRS, followed by Professional Accounting Bodies (PAB), Financial Reporting Council of Nigeria (FRCN)), and Legal Frameworks (LEFW). Isenmila and Adeyemo (2013) also assert that Tertiary Educational Institutions (TEDI) are not potentially developed enough to support the ongoing mandatory adoption of IFRS. They finally conclude that a statistically material difference exists in the views of the stakeholders about the adequacy of Nigerian Institutional Infrastructures to support the mandatory adoption of IFRS.

Focussing on the private sector, Okpala (2012) investigated the linkage between IFRS implementation and foreign direct investment (FDI) inflow in Nigeria. The results indicated the existence of a positive significant relationship between IFRS adoption and foreign direct investment in the country with the resultant effect of boosting investors' confidence, thus leading to cross border financial transactions The survey also revealed that the adoption of IFRS will enhance firms' access to global funds thereby propelling them to undertake cross border investments. The study further revealed that so far, IFRS adoption has not resulted in the preparation of timely, reliable and accurate financial statements in Nigeria.

Okafor and Ogiedu, (2011) also assessed the potential gains to the country for embracing and implementing the provisions of IFRS from the perspective of stakeholders. The study found that International Financial Reporting Standards have the potential for yielding greater benefits than current GAAP, improve business performance management and impact on other business functions apart from financial reporting. The study also finds that IFRS provisions and implementation will add to financial reporting complexities and increase compliance with accounting standards.

A lot of research has equally been carried out in terms of improvements in financial reporting quality in many jurisdictions due to voluntary IFRS adoption. According to Gassen and Sellhorn (2006) and Hung and Subramanyam (2007) some of these improvements include: decrease in information asymmetry between management and equity owners, better assets and income management, reduced borrowing costs, and improvement in forecasting competence of the actual and potential investors about the future income of firms. Gordon (2008) also listed the benefits arising from implementing IFRS provisions over the world as: more reliable, timely and accurate financial information for stakeholders; improvements in comparability and transparency of operating results; increased ability to obtain capital across international boundaries; better management and evaluation of global operations; and substantial reduction in cost of borrowing.

To further confirm the benefits of implementation of IFRS Barth, Landsman, Land \& Williams (2008) using firms from different countries that freely implemented IFRS before 2003 indicates appreciable reduction in earnings manipulation by management, more timely and adequate provisions for losses from operation compared to firms that employed local GAAP.

\section{Research Design}

The research design employed in this study is the survey method. The population of the study was all the preparers and users of corporate reports. These include Practicing accountants-PA (auditors), Academic accountants-AA (Educators), regulators-REG of the accounting profession, Industry accountants-IA (accountants operating in the financial, commercial and industrial sectors of the economy) and the Investment analyst - INVA. The industry accountant represents the preparers based on their expertise about IFRS and its adoption. In the same vein Investment analysts-INVA represent the users in support of the views of Healy and Palepu (2001), Clement and Tse, (2003) and Mangena (2004) that investment analysts are main users of financial reports. Their inclusion is also in recognition of Baker (1998) assertion that the roles of investment analysts in the reporting chains require them to have sufficient accounting knowledge to enable them to analyze financial reports and make informed decisions Thus, the provision of information that meets the needs of the analysts is considered as also meeting most of the needs of other users.

The Financial Reporting Council (FRC) represents the regulators while all the accounting lecturers in universities 
represent the educators. Finally, all the licensed auditors in the country represent the practicing accountants.

A sample size of 250 respondents which consists of 50 samples from each of the five categories of the population identified earlier were drawn for the study using simple random sampling techniques. The preparers were chosen from firms operating in an industrial sector with a minimum of five firms and quoted on the Nigerian Stock Exchange between 2002 and 2011. In addition, the 50 samples from the investment analysts group were drawn from firms in the register of members of Capital Market Operators duly compiled by the Nigerian Stock Exchange. The 50 samples of the academic accountants were drawn from the federal, state and private universities in Edo and Lagos States of Nigeria while a sample of 50 practicing accountants (auditors) were selected from firms of chartered accountants in Edo and Lagos states. In the same vein, the 50 samples from the regulators were chosen from the middle and top management staff of Financial Reporting Council formerly called the Nigerian Accounting Standard Board (NASB).

The primary data for the study were obtained through a questionnaire divided into two sections. Section one deals with biographic information of respondents while part two were made up questions that captured the opinion of respondent groups on the adoption and implementation of IFRS. The respondents were asked to answer the questions on a five-point Likert scale in which (5) indicates strongly agreed and (1) strongly disagreed.

Descriptive and inferential statistics were employed in analysing the data obtained. The hypotheses formulated for the study were tested with the use of analysis of variance (ANOVA). The hypotheses tested in the study were:

$\mathrm{H}_{0}: \mu 1=\mu 2=\mu 3=\mu 4=\mu 5$

$\mathrm{H}_{1}: \mu 1=\mu 2 \neq \mu 3=\mu 4=\mu 5$

where: $\mu=$ mean, $1-5=$ respondent groups.

Table 1 showing demography details and category of respondents

\begin{tabular}{lllll}
\hline & & Frequency & Percent & Cumulative percentage \\
\hline Gender & Male & 150 & 73.00 & 73 \\
& Female & 55 & 27.00 & 100 \\
Total & 205 & & \\
Respondent category & Single & & & \\
& Married & 67 & 32.68 & 32.68 \\
& Total & 138 & 67.32 & 100 \\
& & & \\
& Industry Accountants & 44 & 21.50 & 21.50 \\
& Investment Analysts & 34 & 16.59 & 38.09 \\
& Practising Accountants & 45 & 22.00 & 60.09 \\
& Academic Accountants & 43 & 20.90 & 80.99 \\
& Regulators & 39 & 19.01 & 100 \\
Total & 205 & & \\
\hline
\end{tabular}

Source: Researchers' computation, 2013.

Table 1 presents the demographic details of the respondents. From the two hundred and fifty copies of the questionnaire administered, two hundred and twenty copies were returned out of which two hundred and five copies were found usable and analysed. This shows a total response rate of eighty-eight per cent (88\%) for all the groups of respondents

Test of hypothesis 1: The perception of stakeholder groups regarding the impact of IFRS on the quality of financial reporting is the same.

Table 2. Quality of financial statements

\begin{tabular}{lllllll}
\hline Statements & & Sum of squares & Df & Mean Square & F & Sig \\
\hline Adoption of IFRS improves & Between groups & 1005.179 & 4 & 335.060 & 46.398 & 0.000 \\
quality of financial reporting & Within groups & 1003.804 & 200 & 7.222 & & \\
in Nigeria & Total & 2008.983 & 204 & & & \\
\hline
\end{tabular}

Source: Researchers' computation, 2013. 
Table 3. Quality of investment decisions

\begin{tabular}{lllllll}
\hline Statements & & Sum of squares & Df & Mean Square & F & Sig \\
\hline Impact of adoption of & Between groups & 0.080 & 4 & 0.028 & 0.179 & 0.912 \\
IFRS on the quality of & Within groups & 20.538 & 200 & 0.148 & & \\
investment decisions. & Total & 20.618 & 204 & & & \\
\hline
\end{tabular}

Source: Researchers' computation, 2013.

Table 4. Comparability and transparency of financial statements

\begin{tabular}{lllllll}
\hline Statements & & Sum of squares & Df & Mean Square & F & Sig \\
\hline Adoption of IFRS on & Between groups & 0.110 & 4 & 0.038 & 0.240 & 0.868 \\
$\begin{array}{l}\text { comparability and } \\
\text { transparency of financial }\end{array}$ & Within groups & 21.192 & 200 & 0.153 & & \\
statements. & & 21.302 & 204 & & & \\
\hline
\end{tabular}

Source: Researchers' computation, 2013.

Table 2 shows the results of the Analysis of Variance. From the table with a p-value less than 0.05 at $5 \%$ level of significant, the null hypothesis that the perception of stakeholder groups regarding the impact of IFRS on the quality of financial reporting is not materially different is rejected. This means that there is a (statistically) material difference in the perception of stakeholder groups regarding the impact of IFRS on the quality of financial reporting in Nigeria Test of hypothesis 2: The opinion of stakeholder groups regarding the impact of IFRS on the quality of investment decisions is not significantly different

Table 3 shows the results of the Analysis of Variance. From the table with a p-value greater than 0.05 , the null hypothesis that there is no significant difference in the perception of respondent groups regarding the impact of IFRS on the quality of investment decisions is accepted. This means that the perception of respondent groups regarding the impact of IFRS on the quality of investment decisions is the same.

Test of hypothesis 3: The opinion of stakeholders groups on the effects of the implementation of IFRS on comparability and transparency of financial statements is the same. The result of the hypothesis is presented in Table 4. From the table with a p-value greater than 0.05 , the null hypothesis that the views of the stakeholders on the effects of the implementation of IFRS on comparability and transparency of financial statements is not materially different is accepted. This means that the perception of respondent groups regarding the impact of IFRS on comparability and transparency of financial statements in Nigeria is the same.

\section{Discussion of Findings}

The failures of giant corporate organisations across the globe have led to a detail investigation of the auditing, financial reporting and disclosure practices globally. This state of affairs has had harmful effects on the trustworthiness of the accounting and auditing profession. The current study examined stakeholders' perception of the implementation of the provisions of the international financial reporting standards (IFRS) in Nigeria.

The views of 205 sampled stakeholders out of the 250 respondents sampled were used. The respondents consisted of five target groups: industry accountants, investment analyst, practicing accountants, academic accountants and regulators of the accounting profession. Primary data were obtained from the targeted respondents through a questionnaire. The data collected were analysed using both descriptive and inferential statistics.

The results of the first hypothesis show that significant differences exist in the opinion of stakeholders groups regarding the influence of the adoption of IFRS on the quality of financial reporting in Nigeria. This result may be a reflection of the various professional experiences and training backgrounds of the respondents. For example, respondents whose professional and work experience have limited them to old reporting environments may not appreciate the potential benefits of the new financial reporting system.

The study also made inquiries into the stakeholders' opinion on the impact of the adoption of IFRS on the quality of investment decisions in Nigeria. Respondents were varied in their opinion of whether the implementation of IFRS has increased the quality of investment decision in Nigeria. Consequently significant variations exist in the perception of respondents group on the impact of the implementation of IFRS on the increase in the number of companies quoted on the floor of the Nigerian Stock.

From the results of the third hypothesis, it also appears that there were no significant differences among the stakeholders group on whether the adoption of IFRS in Nigeria has enhanced comparability and transparency of financial statements and by extension the reduction in corporate frauds. Although, this result indicates that stakeholders were unanimous in their opinion, those who held contrary views may have been affected by their professional experience, background and training. For example, those stakeholders who have lost substantial part of 
their investments in the Nigerian capital market due to the recent global financial crisis might have attributed the financial loss to the unethical practices of management and therefore may not appreciate the revolutionary positive impact of the implementation of IFRS in Nigeria. Nevertheless, respondents were unanimous in their perception that the adoption of IFRS enhances auditors' independence in Nigeria.

\section{Conclusions and Suggestions for Further Future Research}

The main objective of the study was to provide information that would advance the practice of accounting in Nigeria, by seeking the opinion of selected stakeholders on the recent adoption of IFRS. The production of high quality corporate financial reports depends on the internal and external environment of the corporate organisations including the regulatory environment, notwithstanding the adoption of international accounting and auditing standards. Based on the findings, the study recommends that:

Management of corporate organisations must take appropriate internal control measures to ensure that financial statements are prepared in compliance with established standards. Auditors must assert their independence to ensure that audit reports capture the realities of their client financial circumstances; and regulatory authorities, must put in place adequate arrangements for efficient monitoring of regulatory compliance.

The federal government should strengthen the Financial Reporting Council with qualified personnel in order to adequately discharge its functions of standard setting, monitoring of compliance and sanction of violators effectively and effectively. The government should institute an awareness program that would enhance the degree of compliance with accounting requirements by specified business enterprises. Authorities like the Institute of Chartered Accountants of Nigeria (ICAN), the Securities and Exchange Commission (SEC) and the Central Bank of Nigeria $(\mathrm{CBN})$ should work jointly to design an awareness program on the importance of the adoption and implementation of IFRS in Nigeria.

\section{References}

Baker, R. G. (1998). The market for information evidence from finance directors, analysts and fund managers. Accounting and Business Research, 29(1), 3-20. http://dx.doi.org/10.1080/00014788.1998.9729563

Barth, M. E., Landsman W. R., Lang, M. H., \& Williams, C. D. (2008). Accounting quality: International accounting standards and US GAAP, SSRN, 4(3), 28-37.

Clement, M. B., \& Tse, S.Y. (2003). Do investors respond to analysts' forecast revisions as if forecast accuracy is all that matters? The Accounting Review, 78(1), 227-249. http://dx.doi.org/10.2308/accr.2003.78.1.227

Gassen, J., \& T. Sellhorn (2006). Applying IFRS in Germany - determinants and consequences. Betriebswirtschaftliche Forschung und Praxis 58(4).

Gordon, M. (2008). International Financial Reporting Standards and the Accounting profession, Journal of Accounting and Economics, (5)3: 154-163.

Healy, P.M. \& Palepu, K.C. (2001). Information asymmetry, corporate disclosure and the capital markets: a review of the empirical disclosure literature. Journal of Accounting and Economics, (31)5, 405-440. http://dx.doi.org/10.1016/S0165-4101(01)00018-0

Hung, M., \& Subramanyam, K. (2007). Financial statement effects of adopting international accounting standards: The case of Germany. Review of Accounting Studies, 12(4): 623-657. http://dx.doi.org/10.1007/s11142-007-9049-9

Isenmila, P. A. \& Adeyemo, K, A. (2013). Mandatory adoption of international financial reporting standards (IFRS) in Nigeria: The unresolved institutional question, Mediterranean Journal of Social Sciences (1) 4, $175-184$

Mangena, M. (2004). On the perceived importance of disclosure items in Uk interim financial reports: Evidence from the investment analysts. Working paper series, Bradford University.

Okafor, C. \& \& Ogiedu, O. K. (2011). Potential effects of the adoption and implementation of International financial accounting standards (IFRS) in Nigeria, JORIND, (9)2, 345-358

Okpala, K. E. (2012). Adoption of IFRS and financial statements effects: The Perceived Implications on FDI and Nigeria Economy, Australian Journal of Business and Management Research (2)5, 76-83.

Spiceland, J. D., Sepe, J. F., \& Tomassini, L. A. (2001): Intermediate Accounting- Irwin. McGrawHill.

Wilson, E. H., Loraver N. T., Adaeze, C. O., Iheanyi, O. A. (2013). Adoption of International Financial Reporting Standards (IFRS): Insights from Nigerian Academics and Practitioners, Research Journal of Accounting and Finance, (4)6, 177-186. 